Int. J. Dev. Biol. 59: 119-129 (2015)

doi: $10.1387 / \mathrm{ijdb} .150044 \mathrm{bz}$

\title{
Cell death in cancer therapy of lung adenocarcinoma
}

\author{
ANNA ZAGRYAZHSKAYA ${ }^{1}$, KATARINA GYURASZOVA ${ }^{1,2}$ and BORIS ZHIVOTOVSKY*,1,3 \\ ${ }^{1}$ Institute of Environmental Medicine, Division of Toxicology, Karolinska Institutet, Stockholm, Sweden, \\ ${ }^{2}$ Institute of Biology and Ecology, Faculty of Science, Pavol Jozef Šafárik University in Košice, Košice, Slovakia and \\ ${ }^{3}$ Lomonosov Moscow State University, Moscow, Russia
}

\begin{abstract}
Lung cancer is the main cause of all cancer-related deaths in the world, with lung adenocarcinoma (ADC) being the most common subtype of this fatal disease. Lung ADC is often diagnosed at advanced stages involving disseminated metastatic tumors. This is particularly important for the successful development of new cancer therapy approaches. The high resistance of lung ADC to conventional radio- and chemotherapies represents a major challenge to treatment effectiveness. Here we discuss recent progress in understanding the mechanisms of ADC's broad resistance to treatment and its possible therapeutic implications. A number of driving oncogenic alterations were identified in a subset of lung ADCs, making them suitable for targeted therapies directed towards specific cancer-associated molecular changes. In addition, we discuss the molecular aberrations common in lung ADC that are currently being exploited or are potentially important for targeted cancer therapy, as well as limitations of this type of therapy. Furthermore, we highlight possible treatment modalities that hold promise for overcoming resistance to targeted therapies as well as alternative treatment options such as immunotherapies that are potentially promising for improving the clinical outcome of lung ADC patients.
\end{abstract}

KEY WORDS: cell death, apoptosis, lung adenocarcinoma, targeted therapy, chemotherapy, radiotherapy

\section{Introduction}

Cancer is a systemic disorder characterized by an out-ofcontrol cell status with an acquired survival advantage and ability to proliferate, invade, and metastasize (Hanahan and Weinberg, 2000). There are more than 100 types of cancer with distinct tissue distributions, genetic backgrounds and features. General cancer therapy includes radio-, chemo- immune- and photodynamic therapies, as well as targeted therapies directed towards genetic alterations specific to a particular tumor type. In case of solid tumors, the treatment often combines surgical resection of the primary tumor with other types of medication, so called adjuvant therapies. All types of cancer therapy should ultimately lead to the death of cancer cells, mainly through triggering various cell death programs such as apoptosis, autophagy, necrosis, necroptosis (a regulated form of necrosis), or ferroptosis. Resistance to cancer therapy, both intrinsic and acquired, is recognized as the major cause of cancer-related mortality. Genetic and epigenetic aberrations in cancer cells conferring on them altered processing of DNA damage, efflux and metabolism of chemotherapeutic agents, etc., as well as the ability to evade cell death, drive the resistance of tumor cells to cancer therapy (Wilson et al., 2006).
Lung cancer is the leading cause of cancer-related deaths worldwide. It takes more lives than the next three most common cancers combined (colorectal, breast, and prostate) (Fig. 1A) (http://globocan.iarc.fr). Cigarette smoking is considered to be the cause of $80-90 \%$ of lung cancer cases diagnosed, even though only $10-15 \%$ of lifetime smokers develop lung cancer, indicating the role of specific individual genetic alterations/features in the development and progression of the disease (Breuer et al., 2005). Based on histology, lung cancer is classified as small cell lung carcinoma (SCLC), comprising about $15 \%$ of all lung cancer cases, and non-small cell lung carcinoma (NSCLC), representing $\sim 85 \%$ of all lung cancer cases (Chen et al., 2014). According to the World Health Organization (WHO), NSCLC is divided further into three major subtypes: adenocarcinoma (ADC), squamous cell carcinoma (SCC) and large cell lung carcinoma, comprising about $40 \%, 30 \%$ and $10-15 \%$ of all lung cancer cases, respectively (Fig. 1B) (Chen et al., 2014, Gazdar, 2010). SCC is mostly associated

Abbreviations used in this paper: AIR, ionizing radiation; NSCLC, non-small cell lung carcinoma; RT, radiotherapy; SCC, lung squamous cell carcinoma; SCLC, small cell lung carcinoma.

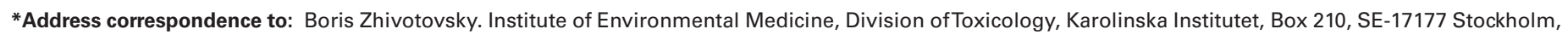
Sweden. E-mail: Boris.Zhivotovsky@ki.seTel: +46-8-5248-7588. Fax: +46-8-32-90-41.
}

Accepted: 16 April 2015.

ISSN: Online 1696-3547, Print 0214-6282 
with smoking history and its incidence rate decreased after the introduction of filtered cigarettes, while the proportion of adenocarcinoma, which is often diagnosed in never-smokers as well, increased within NSCLC, now representing the most frequently diagnosed lung cancer subtype (Breuer et al., 2005).

Despite improvements in the efficacy of cancer therapy, the overall five-year survival rate for lung ADC is still around $15 \%$, with a high recurrence rate in both the developed and developing parts of the world (Imielinski et al., 2012). The initial response to therapy also differs among distinct forms of lung cancer. SCLCs respond well to treatment in earlier stages but are often characterized by tumor aggressiveness and a higher dissemination rate in later stages. Consequently, patients with SCLCs suffer tumor relapse and develop severe resistance to applied anti-tumor therapy. NSCLCs, however, exhibit poor response even in the initial stage compared to SCLCs. Surgical resection with or without adjuvant chemo- and radiotherapy as well as targeted therapy are the common cancer therapies for NSCLCs used in clinics (Larsen et al., 2011).

As non-small cell lung cancer represents highly resistant and fatal tumor type, elucidation of its resistance mechanisms, including those related to alterations in programmed cell death pathways, is extremely important. Here we discuss recent advances in understanding signaling alterations exploited by lung ADC cells, as the most frequent type of lung cancer (Fig. 1B), to evade cell death triggered by conventional radio- and chemotherapies. We also review genetic abnormalities common in lung ADC, the corresponding targeted therapies, and resistance mechanisms to the targeted therapy, as well as recent progress in attempts to overcome this resistance.

\section{Lung adenocarcinoma and associated genetic abnormalities}

As mentioned above, lung ADC is the most common histologic type of lung cancer and the cause of over 600,000 deaths in 2012 worldwide (http://globocan.iarc.fr). ADCs commonly contain a heterogeneous mixture of histological growth patterns, classified as "mixed type"; therefore, new improved guidelines and classification for lung ADC which describe ADCs with different invasive potential as well as its main genetic aberrations, such as epidermal growth factor (EGFR) mutations (see below), have been proposed by international consortia (Travis et al., 2011). In addition to histopathological classification, the use of appropriate biomarkers for specific subtypes of lung ADC would be beneficial for the best choice of anti-cancer therapy (Sakashita et al., 2014).

Lung ADC is a highly complex form of cancer with several subtypes and considerable molecular heterogeneity, as demonstrated by genome-wide sequencing studies (Imielinski etal., 2012). Crucial signaling pathways in ADCs have been reported to be affected by multiple somatic mutations that demonstrated significant correlation with clinical characteristics of the patients (Ding et al., 2008). Interestingly, associations between some mutations in lung ADC and its histological subtype have been demonstrated, such as welldifferentiated distal lung cells expressing thyroid transcription factor 1 (TTF1), often harboring EGFR mutations (Motoi et al., 2008).

Significant efforts have been made to identify clinically relevant activating oncogenic mutations; nevertheless, the mutation status of about $40 \%$ of ADC cases is unknown and requires further investigation (Alamgeer et al., 2013). Genomic abnormalities in lung ADCs were recently reviewed in (Sakashita et al., 2014, Viktorsson et al., 2014); therefore, here we will just list the most common mutations in ADC identified so far. Driving mutations seem to contribute to early carcinogenesis in over $80 \%$ of lung ADC cases (Dearden et al., 2013). Overall, the main genetic aberrations associated with lung ADC include activating mutations in EGFR (15-20\% of all ADC cases), KRAS (25-30\%), BRAF/PIK3CA (2\%), HER2/ MEK (2\%); translocations of anaplastic lymphoma kinase (ALK) (7\%), ROS (1.5\%) and RET (1\%); and amplification of MET (4\%) (Alamgeer et al., 2013). Mutations in EGFR and KRAS are mutually exclusive and demonstrate different distribution patterns in various ethnic groups, with EGFR mutations tending to be less frequent and KRAS mutations more frequent in Western patients compared to the patients of East Asian ethnicity (Dearden et al., 2013, Rosell et al., 2013). The main ADC genetic alterations most often exploited by targeted cancer therapy are EGFR gene mutations (an in-frame deletion in exon 19 and/or a point mutation in exon 21 are the most common) and ALK gene rearrangements, which do not coexist within the same tumor. EGFR is a well-studied member of the ErbB family of tyrosine kinase receptors; it activates downstream PI3K/AKT and RAS/RAF/MAPK signaling pathways known to regulate key cellular functions including apoptosis and proliferation. Within NSCLC, chromosomal rearrangements in ALK, another tyrosine kinase receptor, result in a EML4-ALK

\section{A}

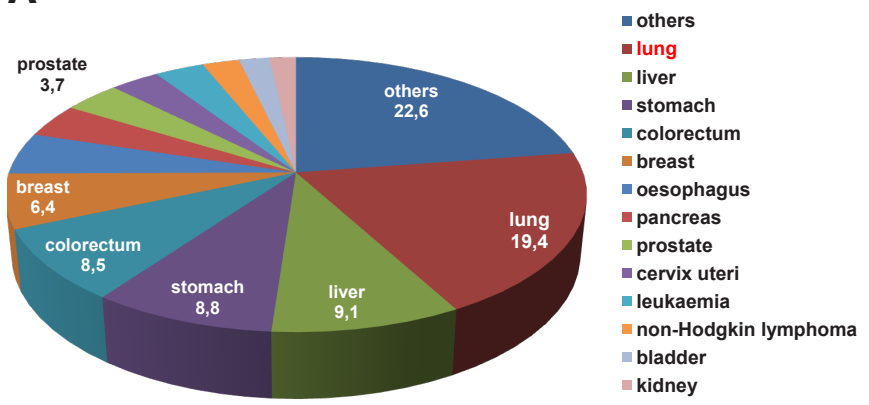

B

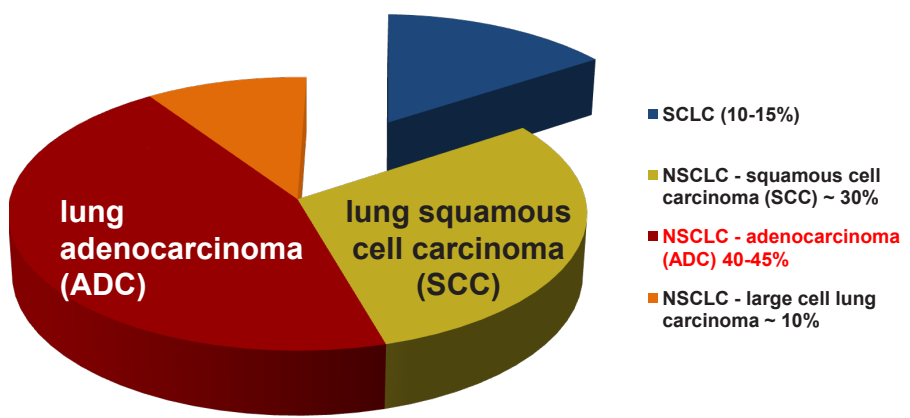

Fig. 1. Worldwide statistical analysis of cancer-related deaths. (A) The percentage of specific cancer-related deaths among all cancer deaths in 2012 in the world. Other cancers include brain, nervous system, corpus uteri, Hodgkin lymphoma, Kaposi sarcoma, larynx, lip, oral cavity, melanoma of skin, multiple myeloma, nasopharynx, ovary, testis and thyroid cancers combined leach type of cancer representing less than 5\% of total cancer incidence/death in the world). Source: GLOBOCAN 2012, IARC. (B) The percentage of different tumor subtypes among all types of lung cancer. 
fusion gene product with constant kinase activity, important for the survival and proliferation of cancer cells (Chirieac and Dacic, 2010). In addition, other potentially cancer-promoting molecular alterations common in lung $A D C$ have been detected in a number of genes including APC, AKT1, TP53, STK1, ATM, EphA3, PTPRD, CDKN2A, and NF-1 (Ding et al., 2008, Viktorsson et al., 2014). Possible therapeutic implications of these new targets are currently under investigation and hold great promise for personalized cancer therapy of lung ADC. Moreover, despite the recent progress made in the development of therapeutic approaches targeting specific genetic changes, acquired resistance to targeted therapy remains a central challenge compromising its efficacy (Chen et al., 2014). To date, conventional radio- and/or chemotherapies still continue to be the first-line treatment for lung ADC (in addition to surgery, whenever possible), with targeted therapy used only at advanced disease stages for subsets of patients with the appropriate genetic alterations. The susceptibility of lung ADC cells to undergoing cell death determines the overall outcome of the cancer therapy (in addition to the therapeutic drug concentration, where applicable) and a number of studies have addressed combinatory treatment approaches affecting multiple signaling pathways regulating cell death mechanisms.

\section{Radioresistance of lung adenocarcinoma}

Radiation therapy (RT), applied as monotherapy or in combination with chemotherapeutic agents, plays an important role in curative and palliative treatment of lung ADC. Ionizing radiation (IR; $\mathrm{X}$-rays or $\gamma$-rays) damages cells by inducing the formation of DNA single- and double-strand breaks (SSBs and DSBs, respectively) leading to activation of the DNA damage response, which, when excessive, leads directly or indirectly to cell death.

Curative RT for the treatment of lung ADC is generally delivered in multiple fractions of IR (typically 2 Gy five times per week) for several weeks. The exact dose of the IR per fraction and total number of fractions may vary according to the type of selected fractionation scheme. Recently, stereotactic body RT (SBRT) has become widely used as a high-dose regimen (up to 30 Gy per fraction) for early stage lung ADC treatment (Heinzerling et al., 2011).

The efficacy of RT is affected by the resistance of cancer cells to treatment as well as the RT tolerance of the surrounding normal tissues. Despite significant efforts, the exact mechanism of cancer cell resistance to $\mathrm{IR}$ is not completely resolved. Tumor relapse due to RT-resistant ADC cells with increased DNA-repair capacity remains a challenging problem in cancer therapy of lung ADC, and the tumor microenvironment has also been shown to play an important role in this process.

Complete tumor eradication is the main goal of RT. However, during fractionated RT accelerated repopulation can compensate for cells killed by IR and contribute to the resistance of irradiated tumor cells. Cancer stem-like cells (CSCs) are known to mediate radioresistance by their ability to self-renew, form new colonies and contribute to repopulation following irradiation (Krause et al., 2011). Significant differences in sensitivity to IR were shown between CSCs and the main tumor cell population in Lewis lung carcinoma. After IR, increased cytochrome $c$ release from mitochondria, elevated intracellular reactive oxygen species (ROS) production, and activation of caspase- 3 and caspase- 9 were detected in the main tumor cell population. In contrast, the CSC population did not show significant changes in any of these parameters (Xia et al., 2013). Moreover, the presence of the CSC phenotype and its correlation with radioresistance were demonstrated in lung ADC. Thus, lung ADC cells surviving after IR expressed significantly higher levels of CSC and embryonic stem cell markers. Upon irradiation, these cells showed the ability to self-renew and generate differentiated progeny (Gomez-Casal et al., 2013). Similar results were obtained by another group that revealed substantial expansion of the lung adenoma CSC population following irradiation, characterized by a two-fold increase in resistance to IR (Desai et al., 2014a). Furthermore, lung ADC CSCs were shown to possess high migration and invasion capacity (Zhang et al., 2014a) and diminished apoptotic response in vitro and in vivo (Lundholm et al., 2013). The radioresistance of CSCs and their accelerated repopulation capability represent a hurdle for successful tumor eradication by RT. The high RT-sensitivity of surrounding tissues allows RT-resistant CSCs to survive and form new colonies. The development of new approaches such as SBRT that are able to deliver high levels of IR precisely to the tumor tissue can help to achieve more effective local tumor control.

Hypoxia is a common feature of solid tumors. It is caused by multiple factors including impairment of tumor vascularization and limited oxygen supply. Hypoxia influences the resistance to IR and is associated with an unfavorable prognosis and poor clinical outcome. Hypoxic tumor cells demonstrate significantly greater resistance to IR compared to well-oxygenated cells. The exact mechanism is not fully understood, but includes an impaired interaction of molecular oxygen with IR-induced DNA radicals, leading to decreased DNA damage (Willers and Held, 2006). Moreover, in lung ADC it was shown that hypoxia led to increased cell viability, clonogenic potential and proliferation, while suppressing apoptosis (Kim et al., 2012b, Li et al., 2014c, Liu et al., 2010). Therefore, it is of great importance to implement tumor hypoxia measurements into lung cancer therapy, an issue that has been addressed by several studies (Meng et al., 2012). Carbonic anhydrase IX (CAIX), one of the markers of hypoxia, is highly overexpressed under hypoxic conditions (Kim et al., 2005, Le et al., 2006). It was shown that CAIX expression in tumor tissues can serve as a predictive marker for clinical outcome for patients with lung ADC. CAIX expression correlated with shorter overall and disease-specific survival (Ilie et al., 2010, Ostheimer et al., 2014). Overexpression and stabilization of CAIX and hypoxia-inducible factor 1 (HIF-1), the major transcriptional activator of the hypoxic response, were shown to contribute to the radioresistance of lung ADC cells, the shift towards a more glycolytic phenotype and a decreased apoptotic response (Grosso et al., 2013).

The expression level of the phosphoglycoprotein osteopontin (OPN) was found to represent another marker for hypoxia and clinical outcome for patients with NSCLC, including lung ADC (Hu et al., 2005, Le et al., 2006, Rud et al., 2013, Zhang et al., 2014b). A potential role of OPN in the radioresistance of lung ADC was revealed by recent studies where overexpression of OPN was associated with a decrease in apoptotic response (Stemberger et al., 2014) and autophagy (Chang et al., 2012). On the other hand, knock-down of this protein led to a significant increase in radiosensitivity, accompanied by cell cycle arrest, suppression of cell proliferation and decreased migration capacity (Polat et al., 2013).

The ability of cancer cells to repair IR-induced DNA damage represents another critical factor for determining the radiosensi- 
tivity of cancer cells. Increased DNA damage repair capacity is a common feature of many types of cancer and plays an important role in clinical outcome (Curtin, 2012). RT-resistant lung ADC cells were shown to have upregulated expression of DSB repair genes and enhanced DSB repair capacity (Desai et al., 2014a, Mihatsch et al., 2011). Specific inhibition of DNA-dependent protein kinase and poly-adenosine diphosphate [ADP]-ribose polymerase proteins involved in DNADSB repair significantly increased the sensitivity of ADC cells to IR, inhibited clonogenic survival and induced prosenescent properties of IR in vitro and in vivo (Azad et al., 2014). Recently, another DNA damage related protein, nucleophosmin 1 (NPM1), was shown to be overexpressed in lung ADC and play a role in DNA DSB repair and resistance to IR. Specific inhibition of NPM1 markedly decreased DSB repair, promoted radiationinduced growth delay and increased radiosensitivity (Sekhar et al., 2014). Similarly, degradation of the DNA damage response protein - human single-strand DNA binding protein 1 caused increased sensitivity to IR via impairment of DSB repair (Chen et al., 2015). Silencing of two homologous recombination genes, exonuclease 1 and Rad51, resulted in complete loss of lung ADC cells' expansion and increased radiation sensitivity (Desai et al., 2014a). These data indicate an important role for DNA damage repair in the radioresistance of lung ADC cells. Therefore, targeting proteins involved in DNA damage repair may contribute to sensitizing these cells to RT.

Soluble factors in the tumor microenvironment such as cytokines are recognized as playing important roles in cancer pathogenesis (Dranoff, 2004, Guo et al., 2012). A significant increase in cytokine levels upon irradiation contributing to acquired resistance to IR was recently demonstrated in lung ADC cells (Crohns et al., 2010, Desai et al., 2013, Desai et al., 2014b). Moreover, high cytokine levels in ADC patients correlated with poor prognosis and worse therapeutic outcome of RT (De Vita et al., 1998, Fu et al., 2014, Koh et al., 2012, Li et al., 2014b). Treatment of cells with self-conditioned medium containing autocrine cytokines and growth factors revealed that, upon irradiation, the function of activating transcription factor 2 (ATF-2) was switched from it acting as a transcription factor to a DNAdamage response protein, leading to increased radioresistance of lung ADC cells (Desai et al., 2014b). Recently, involvement of the pro-inflammatory cytokine interleukin 6 (IL-6) in the regulation of radioresistance was shown in lung ADC. A high level of IL-6 in growth media was found to contribute to IR-resistance. IL-6-induced radioresistance was significantly inhibited when aldo-keto reductase AKR1C3 was knocked-down, suggesting that AKR1C3 may be a critical modulator in IL-6 mediated radioresistance of lung ADC (Xie et al., 2013). Altogether, despite the limited data there are strong indications that the tumor microenvironment plays an important role in the radioresistance of lung ADC. Further investigations in this field will shed light on these radioresistance mechanisms and the role of microenvironment in this process that would enable the efficacy of cancer radiation therapy to be increased.

\section{Chemoresistance of lung adenocarcinoma}

To date, conventional chemotherapy remains the most commonly used therapeutic approach to treat lung cancer clinically, including lung ADC. Chemotherapeutic agents target specific pathways related to cell proliferation, such as DNA/RNA and protein synthesis, microtubule assembly/disassembly and mitotic spindle formation, ultimately leading to the activation of cell death mechanisms.

The efficacy of chemotherapy is often limited due to the cancer cells' ability to evade cell death induced by cytotoxic drugs. Since 1976, when p-glycoprotein was discovered as one of the markers of multidrug resistance (Juliano and Ling, 1976), many other cellular alterations have been shown to contribute to both innate (intrinsic) and acquired chemoresistance. A variety of chemoresistance mechanisms, such as molecular alterations that affect the intracellular accumulation of a cytotoxic drug, increase DNA repair capacity and suppress apoptosis, have been described.

The mainstay in cancer therapy of lung ADC is represented by platinum-based alkylating agents such as cisplatin and its analogues, e.g. carboplatin and oxaliplatin. Covalent binding of these platinum-containing compounds to DNA leads to the formation of DNA adducts resulting in distortion of the DNA molecule, inhibition of DNA synthesis and induction of cell death (Kelland, 2007). In clinics, platinum drugs are often combined with other chemotherapeutics such as taxanes (paclitaxel, docetaxel), vinca alkaloids (vinorelbine, vincristine), antimetabolites (gemcitabine, pemetrexed) or topoisomerase inhibitors (doxorubicin, etoposide).

Efficient drug uptake by cancer cells is crucial in order for a drug to accomplish its cytotoxic effect. Copper transporter-1 (CTR-1), the plasma membrane transporter involved in copper homeostasis, has been shown to play an important role in the uptake of platinum drugs and their intracellular accumulation in normal yeast and murine cells as well as cisplatin-sensitive and cisplatin-resistant lung cancer cells (Ishida et al., 2002, Katano et al., 2002, Song et al., 2004). Aclinical study investigating the prognostic value of CTR-1 in NSCLC tissues revealed a positive correlation between expression of CTR-1 and chemotherapeutic response. Furthermore, patients with high CTR-1 expression demonstrated better progression free and overall survival (Chen et al., 2012). A recent study analyzing the relationship between tissue platinum concentration and CTR1 expression in NSCLC specimens further supports these findings. Patients with undetectable levels of CTR-1 had significantly lower tissue platinum concentrations as well as increased tumor size compared to patients with higher CTR-1 expression. Moreover, patients lacking CTR-1 demonstrated no response to treatment, whereas the rest of the groups combined had a response rate of 29\% (Kim et al., 2014).

A strong correlation has been shown between the intracellular concentration of platinum drugs and the efficacy of anticancer treatment (Hall et al., 2008, Kim et al., 2012a, Koga et al., 2000). Overexpression of membrane proteins comprising the ATP binding cassette $(A B C)$ transporter family contributes significantly to an increased efflux of anticancer drugs in many types of cancer. However, the role of $\mathrm{ABC}$ transporter proteins in innate or acquired chemoresistance in NSCLC is not completely elucidated and different groups have obtained contradictory data. These potential difficulties were reviewed recently (Wangari-Talbot and Hopper-Borge, 2013). In the past few years the research in this field has mainly been focused on efflux protein ATPases, the copper transporters. There is evidence that the copper transporters, namely ATP7A and ATP7B, are essential for acquisition of resistance to platinum drugs (Safaei et al., 2004). An association between ATP7A expression and in vitro sensitivity to cisplatin was shown in NSCLC. The study revealed significantly higher expression levels of ATP7A mRNA in cisplatin-resistant than in cisplatin-sensitive tumors, and higher expression of ATP7A in the ADC- than in the non- ADC group 
(Inoue et al., 2010a). High expression of ATP7A led to decreased intracellular cisplatin accumulation in cisplatin-resistant lung ADC cells, and knockdown of ATP7A by siRNA resulted in chemosensitization and induction of apoptosis (Li et al., 2012). Resistant and sensitive human lung ADC xenograft models displayed significant difference in ATP7B expression correlated with resistance to cisplatin (Nakagawa et al., 2008). Similarly, a strong correlation between the ATP7B mRNA expression level and cisplatin chemosensitivity of lung ADC tumor tissues was observed (Inoue et al., 2010b). Although these data indicate the importance of copper transporters for cisplatin resistance, further investigations are required to clarify the involvement of CTR-1, ATP7A and ATP7B in innate or acquired chemoresistance to platinum drugs in lung ADC.

As mentioned above, platinum-based drugs used for ADC treatment are known to covalently bind DNA, leading to the formation of DNA adducts and activation of the DNA damage response (DNA repair mechanisms, cell cycle arrest, programmed cell death signaling) (Siddik, 2003). Nucleotide excision repair (NER) and homologous recombination (HR) are the main DNA damage repair mechanisms. ERCC1 is the main component of NER, which is involved in cleavage of the damaged 5' DNA strand and crosslink repair (Rosell etal., 2003). The expression level of ERCC1 has been shown to be strongly associated with the clinical outcome of lung ADC patients and ERCC1-negative patients appeared to benefit from cisplatin-based cancer therapy (Azuma et al., 2007, Olaussen et al., 2006, Wang et al., 2010, Vilmar et al., 2010). However, recent data did not reveal an association between ERCC1 expression and clinicopathological characteristics or response to platinumbased treatment despite the correlation with cisplatin sensitivity detected in vitro (Li et al., 2014a, Vassalou et al., 2013). Moreover, a significant prognostic and predictive value of ERCC1 expression level was shown for patients with lung SCC but not for those with lung ADC (Muley et al., 2014). A standardization of the methods used to evaluate the importance of ERCC1, such as the utilized antibodies and detection methods, was recently discussed in order to avoid discrepancies (Friboulet et al., 2013, Muley et al., 2014). Further investigations using standardized methods are needed to clarify the exact role of ERCC1 in the platinum resistance of ADC.

The tumor suppressor BRCA1 is involved in regulating homologous recombination, acting as the main modulator of the cellular response to DNA damage, particularly for DSBs (Venkitaraman, 2001). A previous study indicated a role for BRCA1 in modulating the sensitivity to cisplatin in lung ADC (Taron et al., 2004). NSCLC patients with high BRCA1 expression demonstrated a greater response to a platinum-containing chemotherapy and reduced disease progression (Liang et al., 2014), and high BRCA1 expression level was prognostic for a better clinical outcome (Zhao et al., 2014). Several studies revealed a potential role of BRCA1 expression in resistance to the tubulin-targeting drug docetaxel in lung ADC. Low BRCA1 expression was strongly associated with resistance to docetaxel, whereas high BRCA1 expression led to increased docetaxel sensitivity (Boukovinas et al., 2008, Papadaki et al., 2011, Ren et al., 2012, Su et al., 2011). Recently, the involvement of BRCA1 in regulating microtubule dynamics and paclitaxel-induced apoptotic signaling in lung ADC cells was demonstrated. BRCA1 knockdown led to increased microtubule dynamics and impairment of paclitaxel-induced microtubule polymerization. Furthermore, BRCA1 knockdown reduced the association of microtubules with pro-caspase-8, leading to suppression of the apoptotic response and increased resistance to paclitaxel (Sung and Giannakakou, 2014).

Loss of contact inhibition due to aberrant expression of adhesion molecules is common in aggressive metastatic tumors. The switch from an epithelial (adhesive, differentiated) to mesenchymal (migratory, invasive) cell phenotype, known as the epithelial-tomesenchymal transition (EMT), plays an important role in lung cancer progression (Klymkowsky and Savagner, 2009, Sato et al., 2012). Cisplatin-resistant $A 549$ lung ADC cells overexpressing one of the EMT-inducing transcription factors, SNAIL, acquired an EMT phenotype and revealed enhanced cancer stem cell-like features. Knockdown of SNAIL reversed the EMT and attenuated the invasiveness and cancer stem cell-like properties of these cells (Wang et al., 2014). In addition, downregulation of the tumor metastasis suppressor NDRG1 was documented in lung ADC cells resistant to cisplatin. Inhibition of NDRG1, by affecting EMT and invasiveness, promoted lung ADC cell survival and resistance to cisplatin (Liu et al., 2014). Similarly, docetaxel-resistant lung ADC cells possessed an increased migratory and invasive capacity while overexpressing the EMT-inducing transcriptional factor ZEB1. Knockdown of ZEB1 not only reversed the EMT phenotype but, importantly, enhanced the chemosensitivity of resistant lung ADC cells to docetaxel, both in vitro and in vivo (Ren et al., 2013).

Since the discovery of microRNAs (miRNAs) in 1993 (Lee et al., 1993), a large number of studies have demonstrated their potential role in cancer. miRNAs are involved in regulating apoptosis and drug resistance and can be used as biomarkers in NSCLC, including lung ADC (Del Vescovo et al., 2014, Othman and Nagoor, 2014, Rolfo et al., 2014).

Chemoresistance is the supreme obstacle to ADC treatment effectiveness since conventional chemotherapy is the main form of cancer therapy for most patients with lung ADC and, in spite of the recent progress, represents an extremely important research area where further discoveries are urgently needed.

\section{Targeted therapy of lung adenocarcinoma}

Lung ADC patients displaying specific mutually exclusive genetic alterations (see above) benefit from targeted cancer therapy directed towards the pathways associated with the corresponding genetic changes. The genetic abnormalities in lung ADC currently targeted in clinics are EGFR mutations and ALK gene fusions (Camidge et al., 2012, Mok et al., 2009). Tyrosine kinase inhibitors (TKI) approved for cancer therapy of advanced lung ADC include gefitinib (Iressa, AstraZeneca), erlotinib (Tarceva, Roche) and afatinib (Gilotrif, Boehringer Ingelheim) that target EGFR, as well as crizotinib (Xalkori, Pfizer) and ceritinib (Zykadia, Novartis) targeting ALK. ADC patients harboring EGFR or ALK molecular aberrations treated with the corresponding tyrosine kinase inhibitors demonstrated better response rates, progression-free survival and quality of life compared with conventional chemotherapy (Becker and $\mathrm{Xu}, 2014)$. Afatinib is an irreversible EGFR inhibitor, while gefitinib and erlotinib bind to and block the ATP-binding site of EGFR, thus reversibly suppressing its downstream anti-apoptotic and proliferation stimulating signaling. The beneficial effect of TKI in the treatment of lung ADC is thus consistent with the "oncogene addiction" concept as cancer cells, although harboring complex molecular alterations, rely on the signaling of the dominant driving oncogene, or adjusting to the dominant oncogene ("oncogenic 
amnesia"), and its suppression may induce tumor regression (Felsher, 2008, Weinstein and Joe, 2008). Unfortunately, according to the oncogene addiction concept, at a certain point tumors can escape oncogene dependence through additional mutations as well as alterations in other genes (Weinstein and Joe, 2008). Consequently, in clinical practice the majority of patients with lung ADC develop resistance to chronic treatment with TKI in 9-12 months (Chen et al., 2014). Interestingly, there is an overlap between acquired and intrinsic resistance, since the probability and duration of response can be estimated by a number of factors identified at the time of diagnosis.

The mechanisms of acquired resistance to EGFR and ALK inhibitors have recently been discussed (Awad and Shaw, 2014, Becker and $\mathrm{Xu}, 2014)$; therefore, here we will just underline the recent findings. Recurrent secondary mutations in EGFR and ALK acquired in response to TKI treatment have been identified, such as the EGFR-T790M secondary mutation conferring resistance to erlotinib and gefitinib by increasing EGFR's affinity for ATP over the TKIs. The development of more potent EGFR inhibitors may help overcome the resistance acquired due to the appearance of secondary mutations, although afatinib, the irreversible EGFR inhibitor, did not demonstrate a pronounced response improvement (Kim et al., 2012c). A newly designed TKI with activity against the mutated kinase, CO-1686, was shown to be effective in overcoming EGFR-T790M resistance and demonstrated promising initial clinical results (Walter et al., 2013). Crizotinib is a potent inhibitor of ALK as well as MET and ROS1 tyrosine kinases; therefore, not only ALK-positive patients but also patients with MET and ROS genomic aberrations benefit from crizotinib cancer therapy. Acquired resistance to crizotinib develops by multiple mechanisms, including ALK amplification and secondary ALK mutations, with ALK-L1196M being the most common. A number of improved, more potent ALK inhibitors and Hsp90 inhibitors (as ALK is known to be a client of heat shock protein chaperone system) have now been developed and some are already in clinical trials and showing promising results (Awad and Shaw, 2014). The new ALK-targeted therapeutic agent ceritinib was recently approved by the FDA, demonstrating high potency against ALK-positive tumors, including those resistant to crizotinib, although acquired resistance to ceritinib has already been documented (Friboulet et al., 2014).

In addition to secondary mutations, the stimulation of alternative oncogenic pathways represents an important mechanism of acquired resistance to targeted cancer therapy. Activation of the NF-KB signaling pathway has been shown to confer resistance to erlotinib in lung ADC cell lines harboring EGFR mutations, indicating possible therapeutic implications (Bivona et al., 2011). Moreover, the pro-apoptotic protein BIM (BCL2L11) was demonstrated to be required for EGFR TKI-induced apoptosis and restoration of BIM function potentiated the response to EGFR TKI in lung ADC cells and in mouse xenografts (Nakagawa et al., 2013, $\mathrm{Ng}$ et al., 2012). Therefore, therapeutic approaches supporting BIM function are potentially beneficial for lung ADC patients harboring EGFR mutations, specifically, in tumors with low BIM expression levels. In addition, resistance to EGFR TKIs is associated with the epithelialto-mesenchymal transition, potentially related to upregulation of AXL kinase or loss of Mediator Complex Subunit 12 (MED12) (de Bruin et al., 2014). Low expression of neurofibromin (NF1), a negative RAS regulator, was found to confer resistance to EGFR TKIs in lung ADC, suggesting potential therapeutic implications for MEK inhibitors combined with EGFR TKIs for the treatment of drug-resistant T790M-negative ADC (de Bruin et al., 2014).

Furthermore, as a response to ALK-targeted cancer therapy, the aberrant activation of parallel or downstream anti-apoptotic and proliferation stimulating signaling has been shown to include K-RAS mutations, amplification of KIT and activation of EGFR (Awad and Shaw, 2014). KRAS mutations, being frequent in lung ADC, are not established druggable targets; however, KRAS-driven tumors may be treated via targeting signaling pathways downstream from KRAS by combinations of MEK inhibitors plus PIK3CA or AKT1 inhibitors (Rosell et al., 2013). Interestingly, recent studies described novel KRAS inhibitors targeting the cysteine residue of KRAS, commonly mutated in lung ADC, that demonstrated effectiveness in lung ADC cell lines harboring G12C KRAS mutations (Ostrem et al., 2013), indicating possible therapeutic implications.

Looking beyond EGFR and ALK molecular aberrations, other most clinically relevant targets in lung ADC include ROS1 and RET gene rearrangements, HER2 (ERBB2), PIK3CA, BRAF and CTNNB1 mutations (Bittner et al., 2014). Therapeutic agents targeting these genetic alterations are in development and hold great promise for improving cancer therapy for lung ADC.

\section{Combinatory treatment of lung adenocarcinoma}

Lung ADC as well as many other types of cancer can evade a certain state of oncogene addiction via acquiring additional genetic alterations as a result of various cancer-associated factors, including tumor heterogeneity and genomic instability. Therefore a single targeted therapy agent is generally not sufficient to achieve longlasting cancer remission or cure, especially in advanced disease stages. Accordingly, clinical practice with tyrosine kinase inhibitors used to treat patients with lung ADC harboring EGFR and ALK genetic alterations demonstrated the development of acquired resistance to TKI via different mechanisms in the majority of the patients. To overcome this problem several treatment approaches have been suggested. The targeted therapy may be discontinued and replaced with conventional platinum based chemotherapy. Rapid cancer progression ("disease flare") was reported in NSCLC patients who discontinued EGFR TKIs while awaiting further chemotherapy, indicating the necessity for possible minimization of washout periods for patients when switching to another treatment modality (Chaft et al., 2011). However, regain of sensitivity upon retreatment with erlotinib (after a "drug holiday") was demonstrated for NSCLC patients who switched to conventional chemotherapy but responded initially to erlotinib (Becker et al., 2011). Moreover, there are indications of improved clinical outcome for patients continuing TKIs after initiating chemotherapy (Goldberg et al., 2013, Yang et al., 2014), as TKI-sensitive clones may still remain after the acquisition of resistance to EGFR TKIs. Larger clinical studies addressing the benefit of TKI continuation after initiation of chemotherapy are ongoing (Becker and Xu, 2014).

The pattern of disease progression is an important factor in the choice of treatment after acquisition of resistance to TKIs targeting EGFR or ALK. A cancer therapy approach involving local therapy such as surgery or RT applied to sites of limited disease progression while continuing TKIs was shown to result in longer disease control (Yu etal., 2013). MultifocalADC progression due to acquired resistance via heterogeneous mechanisms represents the main therapeutic challenge. Re-biopsy upon disease progression with 
subsequent histological examination and assessment of additional molecular alterations is important for determining the further direction of cancer therapy. In about $5 \%$ of cases, acquired resistance to EGFR TKI involved histologic transformation of drug-sensitive $A D C$ to drug-resistant SCLC that would require treatment with SCLC-specific chemotherapy (de Bruin et al., 2014, Sequist et al., 2011). Another mechanism of acquired TKI-resistance involves the acquisition of additional molecular aberrations favoring "bypass" signaling that promotes survival and proliferation of cancer cells. Studies including combinations of inhibitors targeting "bypass pathways" such as MET, HER, AKT, PIK3CA, IGFR or Hsp-90 or the use of more potent targeted therapeutic agents are underway and hold great promise for cancer therapy effectiveness. Despite the potential benefit of targeting multiple oncogenes simultaneously, targeting multiple signaling pathways can be highly deleterious to normal cells and may limit the clinical use of this approach. The alternative is to develop more potent single pathway inhibitors or a combination of agents targeting the same signaling cascade, together with drug dosage optimization (Chen et al., 2014, Guan et al., 2014).

It is of great importance that cancer therapy target malignant cells in the context of the entire tumor that contributes to cancer progression, such as tumor vasculature and associated stromal and immune cells. Angiogenesis, a pivotal physiological process of new blood vessel formation from pre-existing ones, is crucial for cancer progression as it results in an oxygen and nutrient supply to tumor cells and promotes metastatic dissemination. A survival benefit for ADC patients treated with a monoclonal antibody against vascular endothelial growth factor A (VEGF-A), bevacizumab, combined with standard platinum based chemotherapy (carboplatin plus paclitaxel) was demonstrated, although accompanied by greatly increased toxicity (Sandler et al., 2006). However, combination of immunotherapies with anti-angiogenic agents has been reported to be effective and potentially beneficial for the clinical outcome of NSCLC patients (Schoenfeld et al., 2010). Although currently immunotherapy is not an established therapeutic modality to treat NSCLC, including ADC, recent progress in this field opens new avenues for the implementation of immunotherapy in the treatment of ADC. One promising immunotherapeutic approach exploits antibodies targeting immunosuppressant proteins such as programmed death ligands (PDL1/2), CD47, CD73, and cytotoxic T lymphocyte protein 4 (CTLA-4) expressed by cancer cells in order to evade recognition and destruction by the host immune system. Overexpression of PDL1 and PDL2 was recently demonstrated in lung ADC, where it was associated with a more advanced ADC stage and poorer prognosis, thus supporting the potential of programmed death-1 (PD-1) blockers for cancer therapy of lung ADC (Zhang et al., 2014c). Studies addressing CTLA-4 blockade in non-squamous NSCLC are in clinical trials and hold promise for cancer therapy (Grosso and Jure-Kunkel, 2013), especially as these agents can potentially be combined with inhibitors of angiogenesis, thus improving treatment effectiveness. Another interesting cancer therapy approach is represented by treatment with engineered $T$ cell or natural killer cells expressing chimeric antigen receptors (CAR) designed to increase the specificity of effector immune cells to tumor cells (Barrett et al., 2014, Liu et al., 2015, Tal et al., 2014). Initial trials revealed high toxicity associated with this immunotherapeutic method; therefore, further optimizations are necessary to test potential application of this approach for cancer therapy of lung ADC (Lee et al., 2012). Furthermore, stromal cells such as fibroblasts are involved in the intercellular contacts and signaling contributing to tumor progression, as well as its resistance to treatment (Straussman et al., 2012, Yoshida et al., 2014), and the role of fibroblast-related signaling in ADC resistance to cancer therapy requires further investigations. In addition, targeting epigenetic enzymes and metabolic alterations in lung ADC may be promising for their therapy (Chen et al., 2014).

Overall, currently in clinics general cure of lung ADC with unknown mutations includes local therapy and/or therapeutic drug combinations containing platinum-based drugs with additional cytotoxic agents such as paclitaxel (mitotic inhibitor) and pemetrexed (folate antimetabolite). For patients with druggable oncogenic mutations, cytotoxic and local therapies are still often required after disease progression due to acquired resistance to EGFR or ALK TKIs. Potential combination therapy including agents targeting different tumor features, such as additional oncogenic aberrations, signaling from stromal cells, metabolic alterations and angiogenesis, as well as immunotherapy approaches to treat lung ADC (Fig. 2) are underway.

\section{Conclusions and final remarks}

Lung ADC is the most common type of the dreadful disease and studies addressing potential improvements in the therapy are urgently needed. Current radio- and chemotherapy approaches are reaching their efficacy limit and, while a number of mechanisms regulating ADC resistance have been discovered, their clinical evaluation and implications are extremely important. Identification of the driving oncogenic mutations in lung ADC provided the basis for targeted therapies and represented a

Fig. 2. Schematic representation of various approaches in lung adenocarcinoma therapy. 
revolutionary step in personalized therapy for ADC. Therefore, the implementation of molecular screening techniques in ADC clinics is highly important, not only at the diagnostic stage but also upon acquisition of resistance to treatment. There are now many strategies aiming to induce ADC cell death and overcome its broad resistance to treatment, including acquired resistance to targeted therapies. These strategies are currently in development and are expected to improve ADC patient outcomes in the near future. Novel approaches directed towards the tumor microenvironment, metabolic changes and new immunotherapeutic approaches represent an intriguing and promising research avenue for improvement of ADC therapy. Detailed investigations addressing possible applications of these approaches to ADC treatment with subsequent clinical implications are anticipated to represent the next level step in cancer therapy for lung adenocarcinoma.

\section{Acknowledgements}

The work in the authors' laboratories was supported by grants from the Russian Science Foundation (14-15-00056) for BZ, the Swedish and Stockholm Cancer Societies, the Swedish Childhood Cancer Foundation, and the Swedish Research Council.

\section{References}

ALAMGEER, M., GANJU, V. and WATKINS, D.N. (2013). Novel therapeutic targets in non-small cell lung cancer. Curr Opin Pharmacol 13: 394-401.

AWAD, M.M. and SHAW, A.T. (2014). ALK Inhibitors in Non-Small Cell Lung Cancer: Crizotinib and Beyond. Clin Adv Hematol Oncol 12: 429-439.

AZAD, A., BUKCZYNSKA, P., JACKSON, S., HAUPT, Y., CULLINANE, C., MCARTHUR, G.A. and SOLOMON, B. (2014). Co-targeting deoxyribonucleic acid-dependent protein kinase and poly(adenosine diphosphate-ribose) polymerase-1 promotes accelerated senescence of irradiated cancer cells. Int J Radiat Oncol Biol Phys 88: 385-394.

AZUMA, K., KOMOHARA, Y., SASADA, T., TERAZAKI, Y., IKEDA, J., HOSHINO, T., ITOH, K., YAMADA, A. and AIZAWA, H. (2007). Excision repair cross-complementation group 1 predicts progression-free and overall survival in non-small cell lung cancer patients treated with platinum-based chemotherapy. Cancer Sci 98: 1336-1343.

BARRETT, D.M., SINGH, N., PORTER, D.L., GRUPP, S.A. and JUNE, C.H. (2014). Chimeric antigen receptor therapy for cancer. Annu Rev Med 65: 333-347.

BECKER, A., CROMBAG, L., HEIDEMAN, D.A., THUNNISSEN, F.B., VAN WIJK, A.W., POSTMUS, P.E. and SMIT, E.F. (2011). Retreatment with erlotinib: Regain of TKI sensitivity following a drug holiday for patients with NSCLC who initially responded to EGFR-TKI treatment. Eur J Cancer 47: 2603-2606.

BECKER, K. and XU, Y. (2014). Management of tyrosine kinase inhibitor resistance in lung cancer with EGFR mutation. World J Clin Oncol 5: 560-567.

BITTNER, N., OSTOROS, G. and GECZI, L. (2014). New treatment options for lung adenocarcinoma--in view of molecular background. Pathol Oncol Res 20: 11-25.

BIVONA, T.G., HIERONYMUS, H., PARKER, J., CHANG, K., TARON, M., ROSELL, R., MOONSAMY, P., DAHLMAN, K., MILLER, V.A., COSTA, C. et al., (2011). FAS and NF-kappaB signalling modulate dependence of lung cancers on mutant EGFR. Nature 471: 523-526.

BOUKOVINAS, I., PAPADAKI, C., MENDEZ, P., TARON, M., MAVROUDIS, D., KOUTSOPOULOS, A., SANCHEZ-RONCO, M., SANCHEZ, J.J., TRYPAKI, M., STAPHOPOULOS, E. et al., (2008). Tumor BRCA1, RRM1 and RRM2 mRNA expression levels and clinical response to first-line gemcitabine plus docetaxel in non-small-cell lung cancer patients. PLoS One 3: e3695.

BREUER, R.H., POSTMUS, P.E. and SMIT, E.F. (2005). Molecular pathology of non-small-cell lung cancer. Respiration 72: 313-330.

CAMIDGE, D.R., BANG, Y.J., KWAK, E.L., IAFRATE, A.J., VARELLA-GARCIA, M., FOX, S.B., RIELY, G.J., SOLOMON, B., OU, S.H., KIM, D.W. et al., (2012). Activity and safety of crizotinib in patients with ALK-positive non-small-cell lung cancer: updated results from a phase 1 study. Lancet Oncol 13: 1011-1019.

CHAFT, J.E., OXNARD, G.R., SIMA, C.S., KRIS, M.G., MILLER, V.A. and RIELY,
G.J. (2011). Disease flare after tyrosine kinase inhibitor discontinuation in patients with EGFR-mutant lung cancer and acquired resistance to erlotinib or gefitinib: implications for clinical trial design. Clin Cancer Res 17: 6298-6303.

CHANG, S.H., MINAI-TEHRANI, A., SHIN, J.Y., PARK, S., KIM, J.E., YU, K.N., HONG, S.H., HONG, C.M., LEE, K.H., BECK, G.R., JR. et al., (2012). Beclin1-induced autophagy abrogates radioresistance of lung cancer cells by suppressing osteopontin. J Radiat Res 53: 422-432.

CHEN, H.H., YAN, J.J., CHEN, W.C., KUO, M.T., LAI, Y.H., LAI, W.W., LIU, H.S. and SU, W.C. (2012). Predictive and prognostic value of human copper transporter 1 (hCtr1) in patients with stage III non-small-cell lung cancer receiving first-line platinum-based doublet chemotherapy. Lung Cancer 75: 228-234.

CHEN, Z., FILLMORE, C.M., HAMMERMAN, P.S., KIM, C.F. and WONG, K.K. (2014). Non-small-cell lung cancers: a heterogeneous set of diseases. Nat Rev Cancer 14: 535-546.

CHEN, Z.W., LIU, B., TANG, N.W., XU, Y.H., YE, X.Y., LI, Z.M., NIU, X.M., SHEN, S.P., LU, S. and XU, L. (2015). FBXL5-mediated degradation of single-stranded DNA-binding protein hSSB1 controls DNA damage response. Nucleic Acids Res 42: 11560-11569.

CHIRIEAC, L.R. and DACIC, S. (2010). Targeted Therapies in Lung Cancer. Surg Pathol Clin 3: 71-82.

CROHNS, M., SAARELAINEN, S., LAINE, S., POUSSA, T., ALHO, H. and KELLOKUMPU-LEHTINEN, P. (2010). Cytokines in bronchoalveolar lavage fluid and serum of lung cancer patients during radiotherapy - Association of interleukin-8 and VEGF with survival. Cytokine 50: 30-36.

CURTIN, N.J. (2012). DNA repair dysregulation from cancer driver to therapeutic target. Nat Rev Cancer 12: 801-817.

DE BRUIN, E.C., COWELL, C., WARNE, P.H., JIANG, M., SAUNDERS, R.E., MELNICK, M.A., GETTINGER, S., WALTHER, Z., WURTZ, A., HEYNEN, G.J. et al., (2014). Reduced NF1 expression confers resistance to EGFR inhibition in lung cancer. Cancer Discov 4: 606-619.

DE VITA, F., ORDITURA, M., AURIEMMA, A., INFUSINO, S. and CATALANO, G. (1998). Serum concentrations of proinflammatory cytokines in advanced non small cell lung cancer patients. J Exp Clin Cancer Res 17: 413-417.

DEARDEN, S., STEVENS, J., WU, Y.L. and BLOWERS, D. (2013). Mutation incidence and coincidence in non small-cell lung cancer: meta-analyses by ethnicity and histology (mutMap). Ann Oncol 24: 2371-2376.

DEL VESCOVO, V., GRASSO, M., BARBARESCHI, M. and DENTI, M.A. (2014). MicroRNAs as lung cancer biomarkers. World J Clin Oncol 5: 604-620.

DESAI, A., WEBB, B. and GERSON, S.L. (2014a). CD133+ cells contribute to radioresistance via altered regulation of DNA repair genes in human lung cancer cells. Radiother Oncol 110: 538-545.

DESAI, S., KUMAR, A., LASKAR, S. and PANDEY, B.N. (2013). Cytokine profile of conditioned medium from human tumor cell lines after acute and fractionated doses of gamma radiation and its effect on survival of bystander tumor cells. Cytokine 61: 54-62.

DESAI, S., KUMAR, A., LASKAR, S. and PANDEY, B.N. (2014b). Differential roles of ATF-2 in survival and DNA repair contributing to radioresistance induced by autocrine soluble factors in A549 lung cancer cells. Cell Signal 26: 2424-2435.

DING, L., GETZ, G., WHEELER, D.A., MARDIS, E.R., MCLELLAN, M.D., CIBULSKIS, K., SOUGNEZ, C., GREULICH, H., MUZNY, D.M., MORGAN, M.B. et al., (2008). Somatic mutations affect key pathways in lung adenocarcinoma. Nature 455: 1069-1075.

DRANOFF, G. (2004). Cytokines in cancer pathogenesis and cancer therapy. Nat Rev Cancer 4: 11-22.

FELSHER, D.W. (2008). Oncogene addiction versus oncogene amnesia: perhaps more than just a bad habit? Cancer Res 68: 3081-3086; discussion 3086.

FRIBOULET, L., LI, N., KATAYAMA, R., LEE, C.C., GAINOR, J.F., CRYSTAL, A.S., MICHELLYS, P.Y., AWAD, M.M., YANAGITANI, N., KIM, S. et al., (2014). The ALK inhibitor ceritinib overcomes crizotinib resistance in non-small cell lung cancer. Cancer Discov 4: 662-673.

FRIBOULET, L., OLAUSSEN, K.A., PIGNON, J.P., SHEPHERD, F.A., TSAO, M.S., GRAZIANO, S., KRATZKE, R., DOUILLARD, J.Y., SEYMOUR, L., PIRKER, R. et al., (2013). ERCC1 isoform expression and DNA repair in non-small-cell lung cancer. N Engl J Med 368: 1101-1110.

FU, Z.Z., GU, T., FU, B.H., HUA, H.X., YANG, S., ZHANG, Y.Q., GAO, L.M. and LI, P. (2014). Relationship of serum levels of VEGF and TGF-beta1 with radiosen- 
sitivity of elderly patients with unresectable non-small cell lung cancer. Tumour Biol 35: 4785-4789.

GAZDAR, A.F. (2010). Should we continue to use the term non-small-cell lung cancer? Ann Oncol 21 Suppl 7: vii225-229.

GOLDBERG, S.B., OXNARD, G.R., DIGUMARTHY, S., MUZIKANSKY, A., JACKMAN, D.M., LENNES, I.T. and SEQUIST, L.V. (2013). Chemotherapy with Erlotinib or chemotherapy alone in advanced non-small cell lung cancer with acquired resistance to EGFR tyrosine kinase inhibitors. Oncologist 18: 1214-1220.

GOMEZ-CASAL, R., BHATTACHARYA, C., GANESH, N., BAILEY, L., BASSE, P., GIBSON, M., EPPERLY, M. and LEVINA, V. (2013). Non-small cell lung cancer cells survived ionizing radiation treatment display cancer stem cell and epithelialmesenchymal transition phenotypes. Mol Cancer 12: 94.

GROSSO, J.F. and JURE-KUNKEL, M.N. (2013). CTLA-4 blockade in tumor models: an overview of preclinical and translational research. Cancer Immun 13: 5.

GROSSO, S., DOYEN, J., PARKS, S.K., BERTERO, T., PAYE, A., CARDINAUD, B., GOUNON, P., LACAS-GERVAIS, S., NOEL, A., POUYSSEGUR, J. et al., (2013). MiR-210 promotes a hypoxic phenotype and increases radioresistance in human lung cancer cell lines. Cell Death Dis 4: e544.

GUAN, Y., ZHAO, H., MENG, J., YAN, X. and JIAO, S. (2014). Dramatic response to high-dose icotinib in a lung adenocarcinoma patient after erlotinib failure. Lung Cancer 83: 305-307.

GUO, Y., XU, F., LU, T., DUAN, Z. and ZHANG, Z. (2012). Interleukin-6 signaling pathway in targeted therapy for cancer. Cancer Treat Rev 38: 904-910.

HALL, M.D., OKABE, M., SHEN, D.W., LIANG, X.J. and GOTTESMAN, M.M. (2008). The role of cellular accumulation in determining sensitivity to platinum-based chemotherapy. Annu Rev Pharmacol Toxicol 48: 495-535.

HANAHAN, D. and WEINBERG, R.A. (2000). The hallmarks of cancer. Cell100:57-70.

HEINZERLING, J.H., KAVANAGH, B. and TIMMERMAN, R.D. (2011). Stereotactic ablative radiation therapy for primary lung tumors. Cancer J 17: 28-32.

HU, Z., LIN, D., YUAN, J., XIAO, T., ZHANG, H., SUN, W., HAN, N., MA, Y., DI, X., GAO, M. et al., (2005). Overexpression of osteopontin is associated with more aggressive phenotypes in human non-small cell lung cancer. Clin Cancer Res 11: $4646-4652$

ILIE, M., MAZURE, N.M., HOFMAN, V., AMMADI, R.E., ORTHOLAN, C., BONNETAUD, C., HAVET, K., VENISSAC, N., MOGRABI, B., MOUROUX, J. et al., (2010). High levels of carbonic anhydrase IX in tumour tissue and plasma are biomarkers of poor prognostic in patients with non-small cell lung cancer. $\mathrm{Br} \mathrm{J}$ Cancer 102: 1627-1635.

IMIELINSKI, M., BERGER, A.H., HAMMERMAN, P.S., HERNANDEZ, B., PUGH, T.J., HODIS, E., CHO, J., SUH, J., CAPELLETTI, M., SIVACHENKO, A. et al., (2012). Mapping the hallmarks of lung adenocarcinoma with massively parallel sequencing. Cell 150: 1107-1120.

INOUE, Y., MATSUMOTO, H., YAMADA, S., KAWAI, K., SUEMIZU, H., GIKA, M., TAKANAMI, I., IWAZAKI, M. and NAKAMURA, M. (2010a). Association of ATP7A expression and in vitro sensitivity to cisplatin in non-small cell lung cancer. Oncol Lett 1: 837-840.

INOUE, Y., MATSUMOTO, H., YAMADA, S., KAWAI, K., SUEMIZU, H., GIKA, M., TAKANAMI, I., NAKAMURA, M. and IWAZAKI, M. (2010b). ATP7B expression is associated with in vitro sensitivity to cisplatin in non-small cell lung cancer. Oncol Lett 1: 279-282.

ISHIDA, S., LEE, J., THIELE, D.J. and HERSKOWITZ, I. (2002). Uptake of the anticancer drug cisplatin mediated by the copper transporter Ctr1 in yeast and mammals. Proc Natl Acad Sci U S A 99: 14298-14302.

JULIANO, R.L. and LING, V. (1976). A surface glycoprotein modulating drug permeability in Chinese hamster ovary cell mutants. Biochim Biophys Acta 455: 152-162.

KATANO, K., KONDO, A., SAFAEI, R., HOLZER, A., SAMIMI, G., MISHIMA, M., KUO, Y.M., ROCHDI, M. and HOWELL, S.B. (2002). Acquisition of resistance to cisplatin is accompanied by changes in the cellular pharmacology of copper. Cancer Res 62: 6559-6565.

KELLAND, L. (2007). The resurgence of platinum-based cancer chemotherapy. Nat Rev Cancer 7: 573-584.

KIM, E.S., LEE, J.J., HE, G., CHOW, C.W., FUJIMOTO, J., KALHOR, N., SWISHER, S.G., WISTUBA, II, STEWART, D.J. and SIDDIK, Z.H. (2012a). Tissue platinum concentration and tumor response in non-small-cell lung cancer. $J$ Clin Oncol 30: 3345-3352.

KIM, E.S., TANG, X., PETERSON, D.R., KILARI, D., CHOW, C.W., FUJIMOTO, J.,
KALHOR, N., SWISHER, S.G., STEWART, D.J., WISTUBA, II et al., (2014). Copper transporter CTR1 expression and tissue platinum concentration in non-smal cell lung cancer. Lung Cancer 85: 88-93.

KIM, S.J., RABBANI, Z.N., DEWHIRST, M.W., VUJASKOVIC, Z., VOLLMER, R.T., SCHREIBER, E.G., OOSTERWIJK, E. and KELLEY, M.J. (2005). Expression of HIF-1alpha, CA IX, VEGF, and MMP-9 in surgically resected non-small cell lung cancer. Lung Cancer 49: 325-335.

KIM, T.R., CHO, E.W., PAIK, S.G. and KIM, I.G. (2012b). Hypoxia-induced SM22alpha in $A 549$ cells activates the IGF1R/PI3K/Akt pathway, conferring cellular resistance against chemo- and radiation therapy. FEBS Lett 586: 303-309.

KIM, Y., KO, J., CUI, Z., ABOLHODA, A., AHN, J.S., OU, S.H., AHN, M.J. and PARK, K. (2012c). The EGFR T790M mutation in acquired resistance to an irreversible second-generation EGFR inhibitor. Mol Cancer Ther 11: 784-791.

KLYMKOWSKY, M.W. and SAVAGNER, P. (2009). Epithelial-mesenchymal transition: a cancer researcher's conceptual friend and foe. Am J Pathol 174: 1588-1593.

KOGA, H., KOTOH, S., NAKASHIMA, M., YOKOMIZO, A., TANAKA, M. and NAITO, S. (2000). Accumulation of intracellular platinum is correlated with intrinsic cisplatin resistance in human bladder cancer cell lines. Int J Oncol 16: 1003-1007.

KOH, E., IIZASA, T., YAMAJI, H., SEKINE, Y., HIROSHIMA, K., YOSHINO, I. and FUJISAWA, T. (2012). Significance of the correlation between the expression of interleukin 6 and clinical features in patients with non-small cell lung cancer. Int J Surg Pathol 20: 233-239.

KRAUSE, M., YAROMINA, A., EICHELER, W., KOCH, U. and BAUMANN, M. (2011). Cancer stem cells: targets and potential biomarkers for radiotherapy. Clin Cancer Res 17: 7224-7229.

LARSEN, J.E., CASCONE, T., GERBER, D.E., HEYMACH, J.V. and MINNA, J.D. (2011). Targeted therapies for lung cancer: clinical experience and novel agents. Cancer J 17: 512-527.

LE, Q.T., CHEN, E., SALIM, A., CAO, H., KONG, C.S., WHYTE, R., DONINGTON, J., CANNON, W., WAKELEE, H., TIBSHIRANI, R. et al., (2006). An evaluation of tumor oxygenation and gene expression in patients with early stage non-small cell lung cancers. Clin Cancer Res 12: 1507-1514.

LEE, D.W., BARRETT, D.M., MACKALL, C., ORENTAS, R. and GRUPP, S.A. (2012). The future is now: chimeric antigen receptors as new targeted therapies for childhood cancer. Clin Cancer Res 18: 2780-2790.

LEE, R.C., FEINBAUM, R.L. and AMBROS, V. (1993). The C. elegans heterochronic gene lin-4 encodes small RNAs with antisense complementarity to lin-14. Cell 75: $843-854$

LI, C., LIU, M., YAN, A., LIU, W., HOU, J., CAI, L. and DONG, X. (2014a). ERCC1 and the efficacy of cisplatin in patients with resected non-small cell lung cancer. Tumour Biol. 35: 12707-12712.

LI, J., WANG, Z., MAO, K. and GUO, X. (2014b). Clinical significance of serum T helper $1 / T$ helper 2 cytokine shift in patients with non-small cell lung cancer. Oncol Lett 8: 1682-1686

LI, X., LIU, X., XU, Y., LIU, J., XIE, M., NI, W. and CHEN, S. (2014c). KLF5 promotes hypoxia-induced survival and inhibits apoptosis in non-small cell lung cancer cells via HIF-1alpha. Int J Oncol 45: 1507-1514.

LI, Z.H., QIU, M.Z., ZENG, Z.L., LUO, H.Y., WU, W.J., WANG, F., WANG, Z.Q. ZHANG, D.S., LI, Y.H. and XU, R.H. (2012). Copper-transporting P-type adenosine triphosphatase (ATP7A) is associated with platinum-resistance in non-small cell lung cancer (NSCLC). J Transl Med 10: 21

LIANG, J.G., JIN, Z.Y., GAO, X.D., TE, M.R., GE, L.H. and WANG, C.L. (2014). Predictive role of RRM1 and BRCA1 mRNA expression on the clinical outcome of advanced non-small cell lung cancer. Genet Mol Res 13: 5292-5298.

LIU, H., GU, Y., YIN, J., ZHENG, G., WANG, C., ZHANG, Z., DENG, M., LIU, J., JIA $X$. and $\mathrm{HE}, \mathrm{Z}$. (2014). SET-mediated NDRG1 inhibition is involved in acquisition of epithelial-to-mesenchymal transition phenotype and cisplatin resistance in human lung cancer cell. Cell Signal 26: 2710-2720.

LIU, H., YANG, B., SUN, T., LIN, L., HU, Y., DENG, M., YANG, J., LIU, T., LI, J., SUN, S. etal., (2015). Specific growth inhibition of ErbB2expressing human breast cancer cells by genetically modified NK92 cells. Oncol Rep 33: 95-102.

LIU, Y., SONG, X., WANG, X., WEI, L., LIU, X., YUAN, S. and LV, L. (2010). Effect of chronic intermittent hypoxia on biological behavior and hypoxia-associated gene expression in lung cancer cells. J Cell Biochem 111: 554-563.

LUNDHOLM, L., HAAG, P., ZONG, D., JUNTTI, T., MORK, B., LEWENSOHN, R. and VIKTORSSON, K. (2013). Resistance to DNA-damaging treatment in non-small 
cell lung cancer tumor-initiating cells involves reduced DNA-PK/ATM activation and diminished cell cycle arrest. Cell Death Dis 4: e478.

MENG, X., KONG, F.M. and YU, J. (2012). Implementation of hypoxia measurement into lung cancer therapy. Lung Cancer 75: 146-150.

MIHATSCH, J., TOULANY, M., BAREISS, P.M., GRIMM, S., LENGERKE, C., KEHL$\mathrm{BACH}, \mathrm{R}$. and RODEMANN, H.P. (2011). Selection of radioresistant tumor cells and presence of ALDH1 activity in vitro. Radiother Oncol 99: 300-306.

MOK, T.S., WU, Y.L., THONGPRASERT, S., YANG, C.H., CHU, D.T., SAIJO, N., SUNPAWERAVONG, P., HAN, B., MARGONO, B., ICHINOSE, Y. et al., (2009). Gefitinib or carboplatin-paclitaxel in pulmonary adenocarcinoma. N Engl J Med 361: 947-957.

MOTOI, N., SZOKE, J., RIELY, G.J., SESHAN, V.E., KRIS, M.G., RUSCH, V.W., GERALD, W.L. and TRAVIS, W.D. (2008). Lung adenocarcinoma: modification of the 2004 WHO mixed subtype to include the major histologic subtype suggests correlations between papillary and micropapillary adenocarcinoma subtypes, EGFR mutations and gene expression analysis. Am J Surg Pathol 32: 810-827.

MULEY, T.R., SIANIDOU, M., THOMAS, M., BISCHOFF, H., DIENEMANN, H., MEISTER, M., SCHNEIDER, M.A., SCHNABEL, P.A. and WARTH, A. (2014). Comparison of two ERCC1 antibodies as prognostic and predictive biomarkers for early non-small cell lung cancer. Anticancer Res 34: 3707-3713.

NAKAGAWA, T., INOUE, Y., KODAMA, H., YAMAZAKI, H., KAWAI, K., SUEMIZU, H., MASUDA, R., IWAZAKI, M., YAMADA, S., UEYAMA, Y. et al., (2008). Expression of copper-transporting P-type adenosine triphosphatase (ATP7B) correlates with cisplatin resistance in human non-small cell lung cancer xenografts. Oncol Rep 20: 265-270.

NAKAGAWA, T., TAKEUCHI, S., YAMADA, T., EBI, H., SANO, T., NANJO, S. ISHIKAWA, D., SATO, M., HASEGAWA, Y., SEKIDO, Y. et al., (2013). EGFR-TKI resistance due to BIM polymorphism can be circumvented in combination with HDAC inhibition. Cancer Res 73: 2428-2434.

NG, K.P., HILLMER, A.M., CHUAH, C.T., JUAN, W.C., KO, T.K., TEO, A.S., ARIYARATNE, P.N., TAKAHASHI, N., SAWADA, K., FEI, Y. et al., (2012). A common BIM deletion polymorphism mediates intrinsic resistance and inferior responses to tyrosine kinase inhibitors in cancer. Nat Med 18: 521-528.

OLAUSSEN, K.A., DUNANT, A., FOURET, P., BRAMBILLA, E., ANDRE, F., HADDAD, V., TARANCHON, E., FILIPITS, M., PIRKER, R., POPPER, H.H. et al., (2006). DNA repair by ERCC1 in non-small-cell lung cancer and cisplatin-based adjuvant chemotherapy. N Engl J Med 355: 983-991.

OSTHEIMER, C., BACHE, M., GUTTLER, A., KOTZSCH, M. and VORDERMARK, D. (2014). A pilot study on potential plasma hypoxia markers in the radiotherapy of non-small cell lung cancer. Osteopontin, carbonic anhydrase IX and vascular endothelial growth factor. Strahlenther Onkol 190: 276-282.

OSTREM, J.M., PETERS, U., SOS, M.L., WELLS, J.A. and SHOKAT, K.M. (2013). K-Ras (G12C) inhibitors allosterically control GTP affinity and effector interactions. Nature 503: 548-551.

OTHMAN, N. and NAGOOR, N.H. (2014). The role of microRNAs in the regulation of apoptosis in lung cancer and its application in cancer treatment. Biomed Res Int 2014: 318030

PAPADAKI, C., TSAROUCHA, E., KAKLAMANIS, L., LAGOUDAKI, E., TRYPAKI, M., TRYFONIDIS, K., MAVROUDIS, D., STATHOPOULOS, E., GEORGOULIAS V. and SOUGLAKOS, J. (2011). Correlation of BRCA1, TXR1 and TSP1 mRNA expression with treatment outcome to docetaxel-based first-line chemotherapy in patients with advanced/metastatic non-small-cell lung cancer. $\mathrm{Br} J$ Cancer 104: 316-323.

POLAT, B., WOHLLEBEN, G., KATZER, A., DJUZENOVA, C.S., TECHNAU, A. and FLENTJE, M. (2013). Influence of osteopontin silencing on survival and migration of lung cancer cells. Strahlenther Onkol 189: 62-67.

REN, J., CHEN, Y., SONG, H., CHEN, L. and WANG, R. (2013). Inhibition of ZEB1 reverses EMT and chemoresistance in docetaxel-resistant human lung adenocarcinoma cell line. J Cell Biochem 114: 1395-1403.

REN, S.X., LI, A.W., ZHOU, S.W., ZHANG, L., WANG, Y.S., LI, B., CHEN, X.X., ZHANG, J., XU, J.F. and ZHOU, C.C. (2012). Individualized Chemotherapy in Advanced NSCLC Patients Based on mRNA Levels of BRCA1 and RRM1. Chin $J$ Cancer Res 24: 226-231.

ROLFO, C., FANALE, D., HONG, D.S., TSIMBERIDOU, A.M., PIHA-PAUL, S.A., PAUWELS, P., VAN MEERBEECK, J.P., CARUSO, S., BAZAN, V., CICERO, G. et al., (2014). Impact of microRNAs in resistance to chemotherapy and novel targeted agents in non-small cell lung cancer. Curr Pharm Biotechnol 15: 475-485.
ROSELL, R., BIVONA, T.G. and KARACHALIOU, N. (2013). Genetics and biomarkers in personalisation of lung cancer treatment. Lancet 382: 720-731.

ROSELL, R., TARON, M., BARNADAS, A., SCAGLIOTTI, G., SARRIES, C. and ROIG, B. (2003). Nucleotide excision repair pathways involved in Cisplatin resistance in non-small-cell lung cancer. Cancer Control 10: 297-305.

RUD, A.K., BOYE, K., OIJORDSBAKKEN, M., LUND-IVERSEN, M., HALVORSEN A.R., SOLBERG, S.K., BERGE, G., HELLAND, A., BRUSTUGUN, O.T. and MAELANDSMO, G.M. (2013). Osteopontin is a prognostic biomarker in non-small cell lung cancer. BMC Cancer 13: 540 .

SAFAEI, R., HOLZER, A.K., KATANO, K., SAMIMI, G. and HOWELL, S.B. (2004). The role of copper transporters in the development of resistance to Pt drugs. J Inorg Biochem 98: 1607-1613.

SAKASHITA, S., SAKASHITA, M. and SOUND TSAO, M. (2014). Genes and pathology of non-small cell lung carcinoma. Semin Oncol 41: 28-39.

SANDLER, A., GRAY, R., PERRY, M.C., BRAHMER, J., SCHILLER, J.H., DOWLATI, A., LILENBAUM, R. and JOHNSON, D.H. (2006). Paclitaxel-carboplatin alone or with bevacizumab for non-small-cell lung cancer. N Engl J Med 355: 2542-2550.

SATO, M., SHAMES, D.S. and HASEGAWA, Y. (2012). Emerging evidence of epithelialto-mesenchymal transition in lung carcinogenesis. Respirology 17: 1048-1059.

SCHOENFELD, J., JINUSHI, M., NAKAZAKI, Y., WIENER, D., PARK, J., SOIFFER, R., NEUBERG, D., MIHM, M., HODI, F.S. and DRANOFF, G. (2010). Active immunotherapy induces antibody responses that target tumor angiogenesis. Cancer Res 70: 10150-10160.

SEKHAR, K.R., BENAMAR, M., VENKATESWARAN, A., SASI, S., PENTHALA, N.R. CROOKS, P.A., HANN, S.R., GENG, L., BALUSU, R., ABBAS, T. et al., (2014) Targeting nucleophosmin 1 represents a rational strategy for radiation sensitization. Int J Radiat Oncol Biol Phys 89: 1106-1114.

SEQUIST, L.V., WALTMAN, B.A., DIAS-SANTAGATA, D., DIGUMARTHY, S., TURKE, A.B., FIDIAS, P., BERGETHON, K., SHAW, A.T., GETTINGER, S., COSPER, A.K. et al., (2011). Genotypic and histological evolution of lung cancers acquiring resistance to EGFR inhibitors. Sci Transl Med 3: 75ra26.

SIDDIK, Z.H. (2003). Cisplatin: mode of cytotoxic action and molecular basis of resistance. Oncogene 22: 7265-7279.

SONG, I.S., SAVARAJ, N., SIDDIK, Z.H., LIU, P., WEI, Y., WU, C.J. and KUO, M.T (2004). Role of human copper transporter Ctr1 in the transport of platinum-based antitumor agents in cisplatin-sensitive and cisplatin-resistant cells. Mol Cancer Ther 3: 1543-1549.

STEMBERGER, C., MATUSAN-ILIJAS, K., AVIROVIC, M., BULAT-KARDUM, L., IVANCIC, A., JONJIC, N. and LUCIN, K. (2014). Osteopontin is associated with decreased apoptosis and alphav integrin expression in lung adenocarcinoma. Acta Histochem 116: 222-229.

STRAUSSMAN, R., MORIKAWA, T., SHEE, K., BARZILY-ROKNI, M., QIAN, Z.R., DU, J., DAVIS, A., MONGARE, M.M., GOULD, J., FREDERICK, D.T. et al., (2012) Tumour micro-environment elicits innate resistance to RAF inhibitors through HGF secretion. Nature 487: 500-504.

SU, C., ZHOU, S., ZHANG, L., REN, S., XU, J., ZHANG, J., LV, M., ZHANG, J. and ZHOU, C. (2011). ERCC1, RRM1 and BRCA1 mRNA expression levels and clinical outcome of advanced non-small cell lung cancer. Med Oncol 28: 1411-1417.

SUNG, M. and GIANNAKAKOU, P. (2014). BRCA1 regulates microtubule dynamics and taxane-induced apoptotic cell signaling. Oncogene 33: 1418-1428.

TAL, Y., YAAKOBI, S., HOROVITZ-FRIED, M., SAFYON, E., ROSENTAL, B., PORGADOR, A. and COHEN, C.J. (2014). An NCR1-based chimeric receptor endows T-cells with multiple anti-tumor specificities. Oncotarget 5: 10949-10958.

TARON, M., ROSELL, R., FELIP, E., MENDEZ, P., SOUGLAKOS, J., RONCO, M.S. QUERALT, C., MAJO, J., SANCHEZ, J.M., SANCHEZ, J.J. et al., (2004). BRCA1 mRNA expression levels as an indicator of chemoresistance in lung cancer. Hum Mol Genet 13: 2443-2449.

TRAVIS, W.D., BRAMBILLA, E., NOGUCHI, M., NICHOLSON, A.G., GEISINGER, K.R., YATABE, Y., BEER, D.G., POWELL, C.A., RIELY, G.J., VAN SCHIL, P.E. et al., (2011). International association for the study of lung cancer/american thoracic society/european respiratory society international multidisciplinary classification of lung adenocarcinoma. J Thorac Oncol 6: 244-285.

VASSALOU, H., STATHOPOULOS, E., FIOLITAKI, G., KOUTSOPOULOS, A., VOUTSINA, A., GEORGOULIAS, V. and MAVROUDIS, D. (2013). Excision-repaircross-complement-1 protein as a prognostic factor in patients with advanced non-small cell lung cancer treated with platinum-based first-line chemotherapy. 
Lung Cancer 82: 324-329.

VENKITARAMAN, A.R. (2001). Functions of BRCA1 and BRCA2 in the biological response to DNA damage. J Cell Sci 114: 3591-3598.

VIKTORSSON, K., LEWENSOHN, R. and ZHIVOTOVSKY, B. (2014). Systems biology approaches to develop innovative strategies for lung cancer therapy. Cell Death Dis 5: e1260.

WALTER, A.O., SJIN, R.T., HARINGSMA, H.J., OHASHI, K., SUN, J., LEE, K., DUBROVSKIY, A., LABENSKI, M., ZHU, Z., WANG, Z. et al., (2013). Discovery of a mutant-selective covalent inhibitor of EGFR that overcomes T790M-mediated resistance in NSCLC. Cancer Discov 3: 1404-1415.

WANG, H., ZHANG, G., ZHANG, H., ZHANG, F., ZHOU, B., NING, F., WANG, H.S. CAI, S.H. and DU, J. (2014). Acquisition of epithelial-mesenchymal transition phenotype and cancer stem cell-like properties in cisplatin-resistant lung cancer cells throughAKT/beta-catenin/Snail signaling pathway. EurJPharmacol723: 156-166.

WANG, X., ZHAO, J., YANG, L., MAO, L., AN, T., BAI, H., WANG, S., LIU, X., FENG, G. and WANG, J. (2010). Positive expression of ERCC1 predicts a poorer platinumbased treatment outcome in Chinese patients with advanced non-small-cell lung cancer. Med Oncol 27: 484-490.

WANGARI-TALBOT, J. and HOPPER-BORGE, E. (2013). Drug Resistance Mechanisms in Non-Small Cell Lung Carcinoma. J Can Res Updates 2: 265-282.

WEINSTEIN, I.B. and JOE, A. (2008). Oncogene addiction. CancerRes68:3077-3080.

WILLERS, H. and HELD, K.D. (2006). Introduction to clinical radiation biology. Hematol Oncol Clin North Am 20: 1-24.

VILMAR, A.C., SANTONI-RUGIU, E. and SORENSEN, J.B. (2010). ERCC1 and histopathology in advanced NSCLC patients randomized in a large multicenter phase III trial. Ann Oncol 21: 1817-1824.

WILSON, T.R., LONGLEY, D.B. and JOHNSTON, P.G. (2006). Chemoresistance in solid tumours. Ann Oncol 17 Suppl 10: x315-324.

XIA, P., GOU, W.F., WANG, J.J., NIU, Z.F., CHEN, S., TAKANO, Y. and ZHENG, H.C. (2013). Distinct radiosensitivity of lung carcinoma stem-like side population and main population cells. Cancer Biother Radiopharm 28: 471-478.
XIE, L., YU, J., GUO, W., WEI, L., LIU, Y., WANG, X. and SONG, X. (2013). Aldoketo reductase $1 \mathrm{C} 3$ may be a new radioresistance marker in non-small-cell lung cancer. Cancer Gene Ther 20: 260-266.

YANG, H., YANG, X., ZHANG, Y., LIU, X., DENG, Q., ZHAO, M., XU, X. and HE, J. (2014). Erlotinib in combination with pemetrexed/cisplatin for leptomeningeal metastases and cerebrospinal fluid drug concentrations in lung adenocarcinoma patients after gefitinib faliure. Target Oncol. 10: 135-140.

YOSHIDA, T., ISHII, G., GOTO, K., NERI, S., HASHIMOTO, H., YOH, K., NIHO, S., UMEMURA, S., MATSUMOTO, S., OHMATSU, H. et al., (2014). Podoplaninpositive cancer-associated fibroblasts in the tumor microenvironment induce primary resistance to EGFR-TKIs in lung adenocarcinoma with EGFR mutation. Clin Cancer Res. 21: 612-651.

YU, H.A., SIMA, C.S., HUANG, J., SOLOMON, S.B., RIMNER, A., PAIK, P., PIETANZA, M.C., AZZOLI, C.G., RIZVI, N.A., KRUG, L.M. et al., (2013). Local therapy with continued EGFR tyrosine kinase inhibitor therapy as a treatment strategy in EGFR-mutant advanced lung cancers that have developed acquired resistance to EGFR tyrosine kinase inhibitors. $J$ Thorac Oncol 8: 346-351.

ZHANG, H., YANG, N., SUN, B., JIANG, Y., HOU, C., JI, C., ZHANG, Y., LIU, Y. and ZUO, P. (2014a). CD133 positive cells isolated from A549 cell line exhibited high liver metastatic potential. Neoplasma 61: 153-160.

ZHANG, T., ZHANG, D.M., ZHAO, D., HOU, X.M., LIU, X.J., LING, X.L. and MA, S.C. (2014b). The prognostic value of osteopontin expression in non-small cell lung cancer: a meta-analysis. $J$ Mol Histol 45: 533-540.

ZHANG, Y., WANG, L., LI, Y., PAN, Y., WANG, R., HU, H., LI, H., LUO, X., YE, T., SUN, Y. et al., (2014c). Protein expression of programmed death 1 ligand 1 and ligand 2 independently predict poor prognosis in surgically resected lung adenocarcinoma. Onco Targets Ther 7: 567-573.

ZHAO, H., ZHANG, H., DU, Y. and GU, X. (2014). Prognostic significance of BRCA1, ERCC1, RRM1, and RRM2 in patients with advanced non-small cell lung cancer receiving chemotherapy. Tumour Biol. 35: 12679-12688. 


\section{Further Related Reading, published previously in the Int. J. Dev. Biol.}

Epithelial-mesenchymal interactions: a fundamental Developmental Biology mechanism. Domenico Ribatti and Marcello Santoiemma

Int. J. Dev. Biol. (2014) 58: 303-306

Revisiting DNA damage repair, p53-mediated apoptosis and cisplatin sensitivity in germ cell tumors.

Francesca Cavallo, Darren R. Feldman and Marco Barchi

Int. J. Dev. Biol. (2013) 57: 273-280

Role of cancer-associated fibroblasts in breast cancer development and prognosis Abdelilah Aboussekhra

Int. J. Dev. Biol. (2011) 55: 841-849

Escape mechanisms after antiangiogenic treatment, or why are the tumors growing again?

Ruslan Hlushchuk, Andrew N. Makanya and Valentin Djonov

Int. J. Dev. Biol. (2011) 55: 563-567

Life-giving caspases: revealing new roles during mouse embryo preimplantation development

Dolores Busso, Calixto Dominguez, Tomas Perez-Acle and Ricardo D. Moreno

Int. J. Dev. Biol. (2010) 54: 857-865

Key apoptosis regulating proteins are down-regulated during postnatal tissue development.

Shane D. Madden, Maryanne Donovan and Thomas G. Cotter

Int. J. Dev. Biol. (2007) 51: 415-424

5 yr ISI Impact Factor $(2013)=2.879$
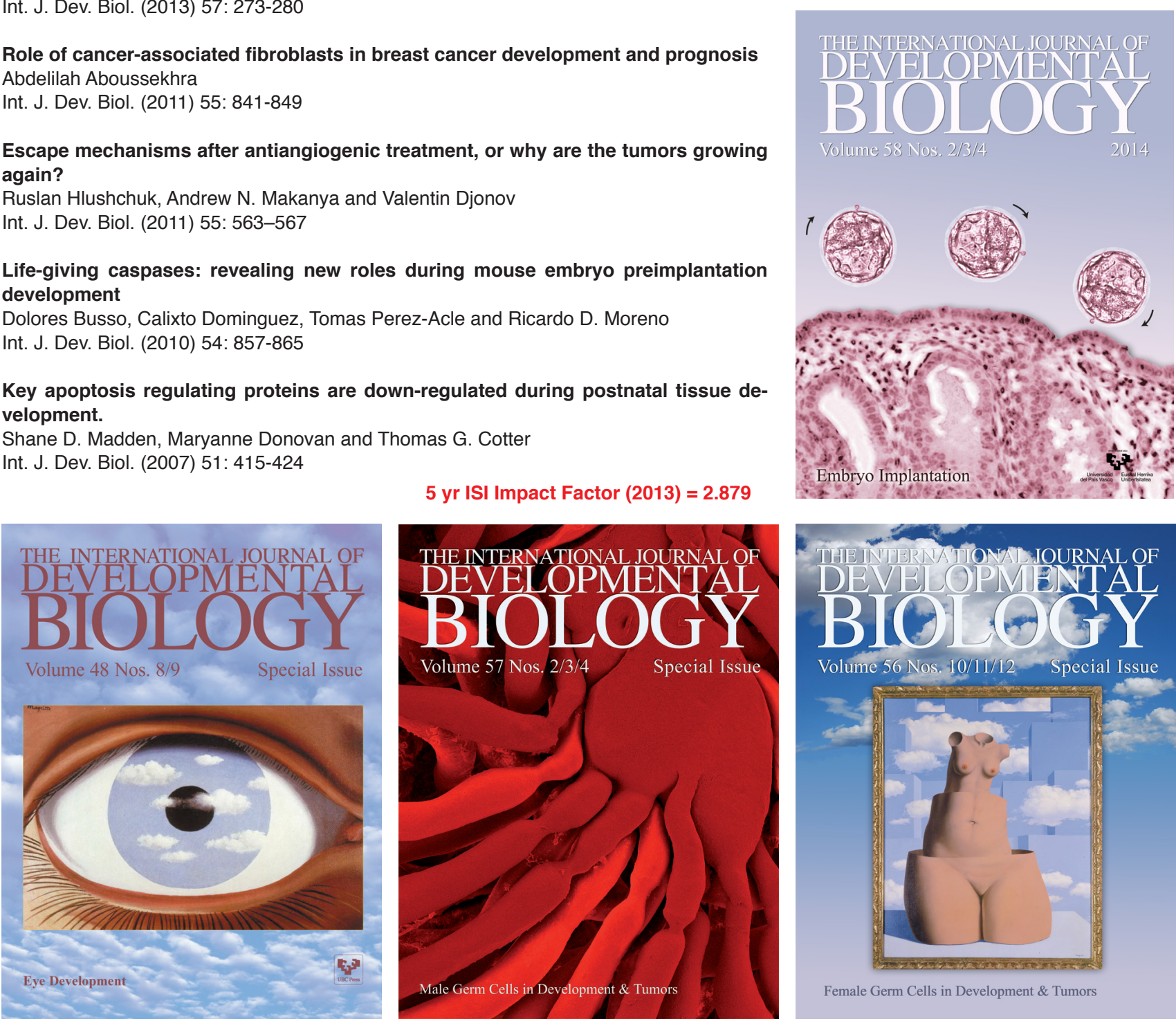

Volume 56 Nos 10/11/12 - Special Issue

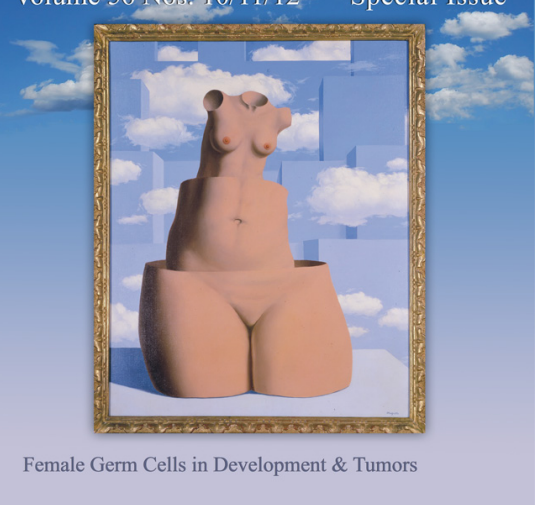

